\title{
"Cardos" of two worlds: Transfer and re- signification of the uses of thistles from the Iberian Peninsula to Argentina
}

J. Esteban Hernández Bermejo $0^{1^{*}}$, Gustavo Delucchi², Gustavo Charra², María Lelia Pochettino ${ }^{2,3}$, Julio Alberto Hurrell2,3*

\begin{abstract}
"Thistles" constitute a group of prickly herbaceous plants included in tribe Cardueae (Asteraceae), but in the popular sense that concept is frequently applied to other species of the same family, as well as to some Dipsacaceae, Bromeliaceae, Apiaceae or Cactaceae. Since antiquity, the cultivation and use of thistles for food and medicinal purposes have been well known in the Mediterranean cultures. The different popular knowledge could allow us to refer to a "thistle culture". During the exploration of America, many of those species and their associated knowledge were transferred from the Old to the New World. In Argentina, several species of thistles, especially Cynara cardunculus, spread extensively throughout the pampas. From early times, they constituted a source of food and low-quality fuel, and in several cases, they were also employed in popular medicine, with diverse uses, some of which are still in practice. The local importance of some species is mentioned in literature, arts, and gastronomy. In the 20th century, a large production of artichokes from introduced crops that increased local agro-diversity was recorded in Argentina. This contribution summarizes some aspects of the transfer and re-signification of the thistle from the Iberian Peninsula to Argentina.
\end{abstract}

Keywords: "Thistle Culture"; Cynara cardunculus; Botanical Knowledge; Ethnobotany

1Departamento de Ingeniería Forestal, Universidad de Córdoba, España; Banco de Germoplasma Vegetal Andaluz, Córdoba, España.

${ }^{2}$ Laboratorio de Etnobotánica y Botánica Aplicada (LEBA), Facultad de Ciencias Naturales y Museo, Universidad Nacional de La Plata, Argentina.

${ }^{3}$ Consejo Nacional de Investigaciones Científicas y Técnicas, Argentina.

*Corresponding author. $\mathrm{E}$ E-mail address: cr1hebee@uco.es, juliohurrell@gmail.com

\section{INTRODUCTION}

The term "thistles" refers to an extensive group of prickly herbaceous plants included in the tribe Cardueae (Asteraceae) that generally display thorns on stems, leaves, and involucral bracts. Nevertheless, the term is also applied in the popular sense to species of other genera of Asteraceae, like Scolymus and Sonchus (Cichorieae), and Xanthium (Heliantheae), as well as to species of prickly plants of other botanical families like Dipsacus (Dipsacaceae), Eryngium (Apiaceae), Argemone (Papaveraceae), Trichocereus (Cactaceae), Ononis (Fabaceae), and several 
Amaranthaceae,

Brassicaceae,

Bromeliaceae, and Zygophyllaceae.

Cardueae includes 73 genera and about 2400 species, mainly of Mediterranean origin (Delucchi and Gutiérrez 2014; Susanna and Garcia-Jacas 2007, 2009). Almost $10 \%$ of the total Cardueae species is represented in the Iberian Peninsula and about 130 species are endemic, some of them with extinction risk (Moreno et al. 2008). Many species naturalized in different world temperate zones, and various cases became weeds or invaders. In Argentinian Flora, 10 genera with 24 species are recorded, just one of which is indigenous: Plectocephalus tweediei (Hook. \& Arn.) N. Garcia \& Susanna (Gutiérrez et al. 2014).

Since antiquity, the cultivation and use of thistles for food and medicinal purposes have been well known in Mediterranean cultures. The ensemble of different popular knowledge could allow us to consider a "thistle culture". From the western Mediterranean (especially the Iberian Peninsula) to America, a partial transference of germplasm and associated knowledge took place (Hernández Bermejo and García Sánchez 1998, 2000). Several species arrived early in Argentina and were widely dispersed over the pampa plains (Gutiérrez and Delucchi 2011). At first, cultivated thistles were a food source; later, naturalized thistles were used as emergency food, medicines, and/or low-quality fuel facing the local shortage of woody plants (Correa et al. 2003; Delucchi et al. 2002; Delucchi and Charra 2012).

In this contribution, we explore the historical antecedents of the use of thistles in ancient Mediterranean cultures and compare that information with different testimonies of their presence and use in Argentina, with a special reference to Cynara cardunculus L., a species of a particular relevance in diverse traditions of that country as it is a conspicuous constituent of local flora both in the wild (Gutiérrez 2011; Gutiérrez et al. 2017) and as a culture (Del Rio et al. 2007).

We have identified a process of "resignification" of the uses of that species, i.e., changes in the meaning of the uses of plants due to modifications in the context of their uses in relation to time and space (Hurrell 2014), including loss of knowledge of the traditions of their origin (food uses in Iberian Peninsula), a partial recovery of those wisdoms due to immigration (Mediterranean food traditions), and a possible local development in Argentina: thistles as alternative resources (medicinal, fuel). The interest of this research is reinforced by today's expectations of cardoons and artichokes (crops included in the genetic heterogeneity of Cynara cardunculus), which can be priority objectives of contemporary horticulture, both in southern South America and in the western Mediterranean.

\section{MATERIAL AND METHODS}

We have applied the approach of historical ethnobotany, including the study of documents from the past (considered as first-hand informants, according to Ochoa and Ladio 2011), and ethnobotanical techniques (like open-ended and semistructured interviews to growers and consumers of thistles, participant observation of the related activities, and the review of current literature) to record present-day uses of thistles in different cultural contexts. The same multidisciplinary approach used in previous studies for both the Iberian Peninsula and Argentina has been applied for research on the past (Correa et al. 2003; Delucchi and Charra 2012; Delucchi et al. 2002; Hernández 
Bermejo 1991; Hernández Bermejo and García Sánchez 1998, 2000, 2015; Hernández Bermejo and León 1994; Hernández Bermejo et al. 1991, 2009, 2013 a, b), based on reviewing historical documents from different archives, accounts from chroniclers, travelers and naturalists, correspondence, and also data obtained from literature, arts, gastronomy, ethnobiological and biological evidences (species distribution, naturalization ways, domestication and genetic processes). In this context, the data provided by travelers that visited the Argentinian pampas during the 16th and 17th centuries have been particularly valuable as they describe local landscape (Delucchi and Charra 2012).

The current documentation sources checked (all of them published, and presented in bibliography list) include: scientific reports of diverse disciplines, ethnographic and anthropological contributions, popular knowledge inventories, texts on pharmacobotany, agriculture, food plants and popular medicine, reports of scientific expeditions, and regional flora published by various authors, official documents, newspaper articles and advertisements. The search was made following references to thistles or well described thorny species, as well as geographical descriptions. Several documents available mention "cardos", being their authors of diverse origin and nature: chroniclers, travelers, navigators, traders, soldiers, functionaries, and scientists (Correa et al. 2003; Delucchi et al. 2002; Delucchi and Charra 2012). Herbaria specimens and data from their labels were also revised. In particular, for the concepts related to naturalization processes we have followed the contribution of Richardson et al. (2000).

Reviewing tasks have been

complemented with botanical and ethnobotanical field work. Botanical work included voucher collections deposited in recognized herbaria: Museo de La Plata (LP), Instituto de Botánica Darwinion (SI), INTA-Castelar (BAB), and identification by means of morphological features. The ethnobotanical research comprised the gathering of samples placed in LEBA collections (La Plata University), micrographic analyses to identify fragmented material, photographic records, and fifty open interviews held with social actors in urban, suburban, and rural areas. In total, twenty five people of both sexes and between 25 and 70 years of age were interviewed. In all cases the informed consent was obtained. The interviewees were selected for their locally recognized knowledge about the uses of thistles, in accordance with qualitative methods and techniques currently employed in ethnobiology (Albuquerque et al. 2014).

\section{RESULTS AND DISCUSSION}

"Cardos" in the historical
documentation of the western
Mediterranean

In Mediterranean cultures, the cultivation and use of "cardos" for food and medicine were well known and have been documented in many references since antiquity. Some species have food or industrial uses, and several are employed in popular medicine due to the presence of active compounds such as sesquiterpene lactones, alkaloids, and bitter principles (Alonso 2004). Nevertheless, thistles have become invasive or weeds in the world temperate zones. Consequently, they are relevant for people not only as useful plants but also due to their negative aspects. 


\section{Ancient history}

Theophrastus (ca. 371-287 BC) includes in his De historia plantarum [ca. 350-287 BC] ('Enquiry into Plants') at least 15 species under the Greek term kaktoi ('cactus' in Latin). The term "cactus" would change its meaning with Linnaeus and was applied to species of genus Cactus (Cactaceae), with thorns (modified leaves) and fleshy stems. This author recorded among them: Carlina acaulis L., C. corymbosa L., C. gummifera (L.) Less., Carthamus tinctorius L., Cirsium arvense (L.) Scop., Cynara cardunculus [more doubtful C. cardunculus subsp. scolymus (L.) Hegi] and Silybum marianum (L.) Gaertn. (Teofrasto 1988).

The Greek Dioscorides (ca. 40-90 BC) cited about 20 species of thistles in his $D e$ materia medica [ca. $65 \mathrm{BC}$ ] ('On Medical Material'), among them: Arctium lappa L. (arkion, "lampazo"), Carduus pycnocephalus ("cardo de calvero"), C. tenuiflorus Curtis ("cardo común"), Carlina acaulis, C. gummifera, Carthamus tinctorius, Centaurea aspera L., C. benedicta (L.) L. ("cardo bendito"), C. calcitrapa L., C. cyanus L., Cynara cardunculus (dubiously $C$. cardunculus subsp. scolymus), Dipsacus fullonum L. (dipsakos), Echinops ritro L. (probably under the name cocodrilium), Eryngium vulgare Lam. (eryngion, "cardo corredor"), Onopordum sp. ("cardo bravío"), Scolymus maculatus L. (skolymos, "cardillo"), Silybum marianum ("cardo mariano" o "cardo lechero") and Sonchus asper (L.) Hill (sónkhostrakhýs, "cerraja") (Font Quer 1961).

The Roman gastronomist Apicius (ca. 25 BC-37 AD), considered the author of De re coquinaria ('The Roman cookery book'), an important source of knowledge of ancient Roman cuisine, records three recipes containing thistles: a) thistles with garo (flavoring sauce made of fish entrails), oil and chopped boiled eggs; b) thistles with crushed rue, coriander leaves, mint and fennel, pepper, wild celery, honey, and oil; c) thistles boiled with mint, cumin, garo and oil (Pastor Artigues 1987).

Columella (4-70 AD), shows interest only in two cultivated species: Cynara cardunculus, praising its use to curdle milk, and Carthamus tinctorius. Nevertheless, in De re rustica [42 AD] ('The Agriculture') the author dedicates a poem to thistles, in which he displays his knowledge of these plants diversity, referring to their morphology and characteristics (Columela 1988).

Pliny the Elder (23-79 AD) mentions at least 15 species in his Naturalis historia [ca. 77] ('Natural History'), some of them difficult to identify, such as Carlina acaulis, C. gummifera, Carthamus tinctorius, Centaurea benedicta, Cynara cardunculus, Echinops ritro, Onopordum sp., Picnomom acarna (L.) Cass., Silybum marianum, Sonchus asper (Plinio 1999).

The Roman agronomist Palladius (4th century), whose life is little known, wrote Opus agriculturae ('Book on agriculture'),a work from late antiquity that has maintained its impact on European agriculture until the 14th century. There he cites Cynara cardunculus (Paladio 1990), and this reference was recuperated by Alonso de Herrera in the 16th century.

\section{Middle Ages}

Cassianus Bassus, "the Byzantine" (4th century), makes a single reference in the Geoponica to Arctium lappa, whose smoke repel plagues, probably alluding to vine pests (Baso 1998). Unfortunately, the Spanish translations available are dubious as in some cases they mention species of Xanthium of American origin. 
The Visigoth Isidoro de Sevilla (556-636), in his Etymologiae [ca. 630] ('The Etymologies') mentions an aromatic and medicinal "centaurea", but it probably refers to Arctium lappa, named "lampazo" by the translator. $\mathrm{He}$ also mentions Cynara cardunculus, identified from a name translated as "cardo" (Isidoro de Sevilla 1982).

The following authors can be selected from about twenty outstanding representatives of Islamic culture in the Iberian Peninsula (al-Andalus). Ibn Bassal ( $\dagger$ 1085), Toledan agronomist, author of Diwān al-filāha ('The Court of Agriculture') (Hernández Bermejo and García Sánchez 1998) mentions the "cártamo" (Carthamus tinctorius) and provides details about its cultivation, its use for dyeing and as a substitute for saffron. Besides, he distinguishes a wild "cártamo" (possibly Carthamus lanatus L.). In addition, the author also cites Cynara cardunculus, and provides data about its cultivation, indicating the difference between the cultivated and wild forms (Ibn Bassal 1995).

The Sevillian agronomist Abū I-Jayr (11th century), the alleged author of Kitābu'Umdat al-abïbfïmarifat al-nabāt ('Physician's basic book for the knowledge of botany for all experts'), is the one most meticulous in the mention of diverse species, taking into account that over 20 different species are identified in this work. Some of them are: Arctium sp., Carlina acaulis, C. gummifera, Carthamus tinctorius ("alazor") and a wild "alazor" (perhaps C. lanatus), Centaurea aspera, C. calcitrapa, Cirsium tuberosum (L.) All., Cynara cardunculus, C. cardunculus subsp. scolymus, Dipsacus fullonum, Eryngium vulgare, Scolymus sp., Sonchus asper, Silybum marianum and Onopordum, about which he says that they are wild "cardos" with deep and strong roots capable of breaking plows (Abū l-Jayr 2004). As for Carlina gummifera, called "liga" (gum), it was used to capture birds. It was named "albataba" by peasants and also, "taparairola" in Toledo, where the name is still current in National Park of Cabañeros, applied to a certain unidentified plant used locally to hunt birds (Verde et al. 2000).

The physician and philosopher Maimonides (1138-1204) refers to the red "flowers" of Carthamus tinctorius used in Cairo as a yellow dye (added to henna) under the name "usfur". In addition, it was used medicinally: as a carminative, laxative, and aphrodisiac (Lev and Amar 2008). There is a confusing reference to "espino blanco" ('white hawthorn') that the translator links to several "cardos", like Picnomon acarna and Onopordum acanthium L.

Another Sevillian agronomist, Ibn alAwwam (ca. 1160), author of the famous Kitāb al-Filāa ('The book of agriculture'), recovers information from Abū l-Jayr, but he selects those species of major agricultural interest: Centaurea benedicta, Cynara cardunculus, C. cardunculus subsp. scolymus and Carthamus tinctorius. In reference to Silybum marianum he mentions two "species", one wild and the other cultivated, that it is sown in September and transplanted in November-December, although the cycle can be delayed, sowing it in January and transplanting in March. After transplanting, it has to be watered once a week, up to rooting. Finally, the author mentions the use of the thorns ("espinas") harvested in August, but he does not mention its destiny (García Sánchez 2009; Ibn al-Awwam 1988).

Ibn al-Baytar (ca. 1180-1248), physician and botanist from Malaga, who wrote Aljami' li-mufradat al-adwiyawa'l-aghdhiya [ca. 1235] ('Compendium of simple drugs and food'), recovers diverse authors, mainly 
classical Greek and Roman ones, and includes plant descriptions that enable their identification. He mentions the arktion (Arctium sp.) plant with a sweet, tender, and white roots, and fruits like cumin. Fruit and root decoction relieves toothache, and heals wounds, and skin cracks caused by the cold. It is consumed as a wine for sciatica and dysuria. About Carthamus tinctorius he says that it colors and aromatizes foods and is also medicinal. Prepared with vinegar it is used for erysipelas and dropsy, and it is also carminative and aphrodisiac. He also warns us that its consumption produces somnolence. This author recognized two Cynara, one cultivated and the other wild, but does not make a clear distinction between thistles and artichokes. The mention of a thistle with leaves similar to those of Carlina acaulis, probably refers to Echinops strigosus L., with a blackish root and thorny capitula, used against scabies. Ibn al-Baytar also addresses the thistle named by Christians "toba" (belonging to genus Onopordum), which are characterized as being highly invasive plants. He also professes a sound knowledge of the ways to consume Silybum marianum, with its broad, large leaves of a similar color to those of "camaleón blanco" (Carlina gummifera), which are consumed young in salads with oil and salt; the capitula are picked when immature, fresh and soft, to be consumed roasted, while their seeds are consumed fried as a snack with wine. In addition, other more elaborate recipes are included, such as in the case of a broth flavored with these seeds that were harvested by HispanicArabs and sold to young Christians under the name of "okub" (the author does not say for what purpose). Minor medicinal uses are mentioned: gum resin of old roots from dry plants was used as an emetic (Ibn al-Baytar 1877).
Ibn Razin al-Tugibi (ca. 1227-1293), a native of Murcia and exiled to Ceuta at 20 years of age, was the author of diverse works of which only the titles have remained. $\mathrm{He}$ also wrote an interesting cook book: Fedalat Al-Jiwan fi tayyibat al-ta'amwa-lalwan [ca. 1240] ('Highlights of the table, on delicacies and stews'), which has only partly survived. Among vegetables there are mentions of eggplants, gourds [Lagenaria siceraria (Molina) Standl.], "alcanería" (Cynara cardunculus var. altilis DC., C. cardunculus subsp. scolymus), wild artichokes (maybe Silybum marianum or Cynara cardunculus var. sylvestris Lam.), "cardillo" (perhaps Scolymus sp.), broad beans, fenugreek, spinach, purslane, lettuce, chard, cauliflower, asparagus, among others. Unfortunately, only those recipes related to eggplants and gourds are available (Ibn Razin al-Tugibi 2007).

A cook book possibly of andalusí origin, entitled 'The Hispano-Maghreb cuisine during the Almohad period', was written in Morocco by an anonymous 13th century author, and it compiles more than 500 recipes, some of them with artichokes in stews with meat, chickpeas, chopped onion, pepper and coriander leaves thickened with bread crumbs and eggs. There is also a reference to a curious way of preparing "cardoon syrup", grinding their petioles with bitter almonds, wild carrots seed, aniseed and "cuscuta"; this preparation is then mixed with three parts of the water in which the chickpeas have been steeped. This mixture is cooked until it is reduced to half its volume, and then marinated, filtered, sweetened with another third part of sugar and honey and flavored with clove, lavender and "wild asaro" (possibly Arum italicum Mill.). Finally, it is boiled until a syrupy thickness is obtained, and it is always drunk with hot water (Huici Miranda 2016). 


\section{16th and 17th centuries in Spain}

Alonso de Herrera (1470-1539) refers extensively to the cultivation of Cynara cardunculus in his Agricultura general [1513] ('Treatise on Agriculture'). The author recognizes many kinds of thistles, explaining that he considers the cultivated in orchards that are called "arrecifes" in some places (Herrera 1818).

The Flemish horticulturist Charles de l'Écluse, known as Carolus Clusius (15251609), wrote Rariorum aliquot stirpium per Hispanias observatorum historia [1576] ('History of the rare species observed in Spain and Portugal). Even when not all species of genus Centaurea can be considered as thistles, among the number he cites is $C$. ornata Willd., a native of Iberian Flora and grown by Belgians as an ornamental plant. He also mentions Carlina corymbosa L., Carthamus caeruleus L. [= Carduncellus coeruleus (L.) C. Presl], Picnomon acarna, Scolymus hispanicus, S. maculatus, and Silybum marianum Clusio (2005).

Miguel de Cervantes Saavedra (15471616), author of the immortal El ingenioso hidalgo Don Quijote de La Mancha [1605] ('The Ingenious Nobleman Sir Quixote of $\mathrm{La}$ Mancha'), showed a sound knowledge of plants as about 150 species can be counted in his works, 100 of them present in the Quijote. Nevertheless, only once are two thistles mentioned, Scolymus hispanicus L.: "my stomach is not made for thistles, or wild pears, or roots of the woods", and Arctium sp.: "He pulled some green leaves from burdock and ivy" (Morales Valverde 2006).

\section{18th, 19th and 20th centuries in Spain}

The ongoing advances achieved during these centuries in the knowledge of Iberian
Flora, initiated with works such as the unfinished Flora Española ('Spanish flora') by Joseph Quer (1762-1764), Gómez de Ortega (1784), and Gómez de Ortega and Muñoz de Ugena (1791-1792), allowed the number of Iberian thistles to increase significantly up to the current level of knowledge. However, at the same time, the number of thistles mentioned in works on agriculture, and even on pharmaceutical botany, decreased.

Esteban Boutelou (1776-1813) and his brother Claudio (1774-1842) authors of Tratado de la Huerta ('Treatise of the orchard'), mention two species: "cardo de España” ('Spanish thistle', Cynara cardunculus) and "cardo espinoso" ('thorny thistle') with large, hard spines (probably Dipsacus fullonum). In the first case, petioles and leaves are eaten after being cured (maybe with vinegar) and cooked. They are also used as horse fodder and are considered to be a healthy food (Boutelou and Boutelou 1801).

Miguel Colmeiro (1816-1901), in his Enumeración y revisión de las plantas de la Península Hispano-Lusitana é Islas Baleares ('Enumeration and revision of the plants Hispano-Lusitanian Peninsula and the Balearic Islands'), summarized the information on Iberian thistles. He cited about 40 Asteraceae especies of Arctium, Atractylis, Carduus, Carlina, Cyrsium, Centaurea, Cynara, Echinops, Onopordum, Picnomon, Scolymus, Silybum, Xanthium, among others (Colmeiro 1885).

The pharmacist Pardo Sastrón (18221909) explains, in his Catálogo o enumeración de las plantas de Torrecilla de Alcañiz, así espontáneas como cultivadas ('Catalogue of the plants of Torrecilla de Alcañiz, both spontaneous and cultivated'), that in the area in the title, located in Teruel province, Aragón, both Cynara cardunculus 
and C. cardunculus subsp. scolymus are cultivated and grow spontaneously in gardens. About the former, he says that the petioles and middle vein of the leaves should be eaten, and that the flowers curdle milk (Pardo Sastrón 1895).

Dantín Cereceda (1881-1963), in his Catálogo metódico de las plantas cultivadas en España ('Methodical catalogue of the plants cultivated in Spain'), included only three thistles: Cynara cardunculus, $C$. cardunculus subsp. scolymus and Scolymus hispanicus (Dantín Cereceda 1943).

Font Quer (1888-1964), in his Plantas medicinales: el Dioscórides renovado ('Medicinal plants, the renovated Dioscorides'), cites around 20 species of medicinal thistles, 12 of them are Cardueae, of the genera Arctium, Carlina, Carthamus, Centaurea, Cynara, Echinops, Mantisalca and Silybum. In addition, he mentions "cardillos" and "cadillos" of the genera Centaurea, Sonchus, and Lactuca, and also the American Xanthium, and a single species of Scolymus. Although not belonging to the Asteraceae family, the set is completed by Dipsacus and Eryngium with 4-5 species. At least 8 of these medicinal species are also used as food, particularly: Cynara cardunculus, C. cardunculus subsp. scolymus, Silybum marianum, Scolymus hispanicus and Carthamus tinctorius (Font Quer 1961).

\section{Thistle species of current ethnobotanical interest in Spain}

At present, there is great expertise in the western Mediterranean in the recording and conservation of thistle germplasm, especially of the Cardueae. In the last 30 years diverse ex situ conservation projects have been developed, addressing domestication, agrodiversity management, phytogenetic resources in seed banks, inventories of traditional knowledge associated with biodiversity, and the study of historical documents on their management in past cultures (Gálvez Ramírez and Hernández Bermejo 1986, 1990; Hernández Bermejo 1991; Hernández Bermejo et al.1991, 2009, 2013 a,b; Hernández Bermejo and García Sánchez 1998, 2015; Pardo de Santayana et al. 2014). That expertise has enabled us to record the traditional uses in the Iberian Peninsula of about 90 taxa of thistles belonging to Asteraceae. Some of them are important, well-known food crops (Cynara cardunculus, C. cardunculus subsp. scolymus, Carthamus tinctorius). Others are of a marginal agricultural interest or are neglected crops (Silybum marianum, Carlina gummifera, Scolymus hispanicus, $S$. maculatus), along with genera with species cultivated as ornamental plants (Carduus, Centaurea, Cirsium, Echinops, Onopordum) or for the pharmaceutical industry (Arctium, Serratula, Silybum). Their ethnobotanical interest is due to the highly diverse uses of the species: food, dyeing, cosmetics, oil, honey production, fodder, handcrafts, magic and psychoactive plants, and especially for their medicinal uses: antibiotic, wound healing, diuretic, febrifuge, purgative, hepatoprotective, cholesterol-lowering, hypoglycemic, anti-hemorrhoidal, antirheumatic, anti-inflammatory, antioxidant.

\section{"Cardos" in the historical documentation of southern South America}

The arrival of the Spanish in South America dates from the first quarter of the 16th century. The first voyages explored littoral areas of the Río de la Plata and Patagonia. Later, in the decades from 1520 to 1540 , the first European settlements took 
place (for instance, the first foundation of Buenos Aires was in 1536). Nevertheless, by 1541 and for a period of 40 years, the region was abandoned although the first colonists left behind cattle and horses. When the Spanish returned (ca. 1580, date of Buenos Aires's second foundation), they perceived that the region was invaded by feral cattle and horses, whose trampling and grazing modified local plant communities and favored the entry of exotic species that, throughout the following centuries, spread over the central region of Argentina. These exotic plants are of relevance due to their weedy character, those outstanding being "cardos" and "abrepuños". Various available documents mention them (Correa et al. 2003; Delucchi et al. 2002; Delucchi and Charra 2012).

1. 16th, 17th and 18th centuries. Chroniclers of the Indies

In the texts of this period, two fundamental aspects can be observed: the introduction of the species known as "cardos" in Europe, along with the spreading of the word "cardo" and its application to American native plant species with similar features. This was a very frequent procedure among the Spanish who arrived in the New World and denominated local plants with the names of plants of their land of origin, based on their similarities. Early references to the plants known as "cardos" in Spain point to both vegetables, previously absent in America, and weeds, that could occasionally be used as emergency food, medicine or fuel.

Antonio Pigafetta (1480-1534) joined the expedition of Fernando de Magallanes and Juan Sebastián Elcano (1519-1522) and wrote Primer viaje alrededor del globo ('Magellan's Voyage around the World'), first published in Italian in 1524. In it he mentions the use of thistles as an emetic by the patagones (native inhabitants of Patagonia) with whom they came in contact (Pigafetta 1986).

The navigator and explorer of Portuguese origin Simón de Alcazaba y Sotomayor (1470-1535) visited the Patagonian coasts. The results of the expedition were written in 1935 in two reports or Relaciones, one by the crewman Juan de Mori, the other by Alonso, the King's notary (Benites 2013; Mori 1941). The thistles importance as emergency food for the explorers is highlighted.

Jerónimo de Vivar (16th century) referred to introduced plants, among them "cardos", in his Crónica y relación copiosa y verdadera de los reinos de Chile [1558] ('Chronicle and abundant and true relation of the kingdoms of Chile') (Vivar 2001).

The German traveler and chronicler Ulrich Schmidl (1510-1581) arrived at the Río de la Plata in 1536 as a member of the expedition of Pedro de Mendoza, and he remained nearly 20 years in the area, as well as in northeastern Argentina and Paraguay. In his Verídica descripción de varias navegaciones como también de muchas partes desconocidas, islas, reinos y ciudades ('True description of several navigations and of unknown islands, kingdoms and cities') of 1567, Schmidl cites the "cardos" that were part of his rations in Buenos Aires (Schmidl 2009).

Alonso González de Nájera (1556-1614), a Spanish soldier participating in the 'Arauco war', in Chile, who reported the use of thistles as emergency food in his Desengaño y Reparo de la Guerra del Reino de Chile [1614] ('Disappointment and Reparation of the War of the Kingdom of Chile') (González de Nájera 1889).

The Chilean Jesuit Alonso de Ovalle 
(1603-1651), in his Histórica relación del Reyno de Chile [1646] ('An historical relation of the kingdom of Chile'), refers to thistles as a garden crop introduced by the Spanish (Ovalle 1646).

Since the second half of the 17th century the idea that "cardos" and "cardales" (thistles populations) were constitutive elements of the pampas landscape had been established. For instance, in the comments of the French engineer Barthélemy de Massiac (1626-1700), who visited Buenos Aires city between 1660 and 1662, and back in Europe published his Mémoires, signed by his brother Pierre (Molina 1955; Salmon 1984). José Cipriano de Herrera y Loizaga (1695-1736) makes similar references in his Viajes de España a Buenos Aires, Córdova, Mendoza, Potosí, Chile i Lima en los años 1713 i 1717 ('Travels from Spain to Buenos Aires, Cordova, Mendoza, Posotí, Chile, and Lima in 1713 and 1717') (Herrera y Loizaga 1785).

In addition, in these and other references, the use of thistles as fuel is mentioned, e.g. the testimony of one anonymous French traveler and that of the Jesuit Michelle Herrein in a letter from 1723 sent to Franz Molinder, Prior of the Austrian Province of the Society of Jesus (Rípodas Ardanaz 2002). Similar mentions are made by Father Pedro Lozano (1697-1752), in his Historia de la conquista del Paraguay, Río de la Plata y Tucumán [1745] ('History of the conquest of Paraguay, Río de la Plata, and Tucumán') (Lamas 1873), and by Alonso Carrió de la Vandera (1715-1783), known as Concolorcorvo, in his work Lazarillo de ciegos y caminantes desde Buenos Aires hasta Lima [1775] ('The guide for blind walkers from Buenos Aires to Lima') (Carrió de la Vandera 1997).

In his Diario del viaje y misión al Río del Sauce realizado en 1748 ('Travel diary and mission to Río del Sauce in 1748') the Jesuit José Cardiel (1704-1782), talking about the reduction of Volcán, near Mar del Plata, Buenos Aires province, mentions the shortage of firewood and the possibility of making it available by sowing wild thistles (Cardiel 1930).

2. 19th, 20th, 21st centuries. Naturalists in Argentina

In this period, the idea that thistles were natives of the pampas was reinforced. For instance, the quotes of British dealers John Parish Robertson (1792-1843) and William Parish Robertson (1794-ca. 1850) can be mentioned. They referred to the existence of huge "cardales" on the road connecting the cities of Buenos Aires and Santa Fe (Parish Robertson and Parish Robertson 1988).

Charles Darwin (1809-1882) writes in his The narrative of the voyages of H.M. Ships Adventure and Beagle. Journal and remarks. 1832-1836: "Near the Guardia [near Buenos Aires] we find the southern limits of two European plants, now become excessively common. The fennel in great profusion covers the ditch banks in the neighbourhood of Buenos Ayres, Monte Video, and other towns. But the cardoon (Cynara cardunculus) has a far wider range: it occurs in these latitudes on both sides of the Cordillera, across the continent. I saw it in unfrequented spots in Chile, Entre Rios, and Banda Oriental (...) I doubt whether any case is on record, of an invasion on so grand a scale of one plant over the aborigines. As I have already said, I nowhere saw the cardoon south of the Salado (...)" (Darwin 1839).

Among others, both Alcide D'Orbigny (1802-1857) in his Viaje a la América Meridional [1826] ('Travel to South America') (D'Orbigny 1945), and William Mac Cann: 
Un viaje a caballo por las provincias argentinas [1847] ('Two Thousand Miles' Ride Through The Argentine Provinces') (Mac Cann 1985) refer to thistles. Their comments mostly address Cynara cardunculus, under the name "cardo de Castilla". Nevertheless, Thomas Woodbine Hinchliff (1825-1882), in his Viaje al Plata en 1861 [1863] ('South American Sketches; or a Visit to Rio Janeiro, The Organ Mountains, La Plata, and the Parana') also cites Silybum marianum (Woodbine Hinchliff 1955).

The first mention of the therapeutic use of thistles as a group belongs to the 19th century in the pioneering work on Argentinian popular medicine by Jorge Hieronymus (1845-1921), Plantae Diaphoricae. Florae Argentinae ('Diaphoretic plants. Argentinian Flora') (Hieronymus 1882). This author includes Centaurea calcitrapa, C. benedicta, C. melitensis, Carthamus tinctorius, Cynara cardunculus, $C$ cardunculus subsp. scolymus, Plectocephalus tweediei and Silybum marianum as the species known as "cardos". Among their diverse uses, those related to their bitter flavor and diseases like "side ache" or jaundice stand out, in accordance with the cholagogue properties of several of these plants (Hurrell and Puentes 2013).

Since then, frequent references to the use of different thistles in local phytotherapy in Argentina have been made in diverse contributions, from, for instance, Marzocca (1977) and Toursarkissian (1980). Several species have been added to those cited by Hieronymus: Carduus acanthoides L., C. tenuiflorus, C. thoermeri Weinm., Cirsium vulgare, Eryngium eburneum Decne., E. horridum Malme, E. pristis Cham. \& Schltdl., Lactuca serriola, Onopordum acanthium, Sonchus asper, S. oleraceus (L.) L., Xanthium spinosum (Martínez-Crovetto $1968,2012)$. These voluminous data of the medicinal use of thistles contrasts with the absence of mentions about food uses. One hypothesis is that their weedy nature impacts negatively on their assessment (Pochettino 2005), thus their relevance in diet remains concealed as they are not positively valued as "edible weeds" (Rapoport et al. 2009).

\section{3. "Thistles" and Cynara cardunculus in} Argentinian arts, literature and folklore

In Argentinian folklore, thistles symbolize the wild, because does not need cares and grow by its own. As an example, in the Martín Fierro by José Hernández (1872): "And they who come into an inheritance, will fall into ruin anywhere. There's no way a man can avoid what fate has decided on. The thistle cannot help pricking you as it is made of thorns" (Hernández 1967).

Even now the thistle is used as a source of inspiration, such as in the case of the tango Ser mina flor de cardo ('Thistle flower girl'), of 1990, with lyrics by Adriana Turchetti and music by Javier González, in which the first verse is used as a synonym for the courage and resistance of women.

Diverse landscapes and plants (thistles in these cases) were depicted by different Argentinian and foreign painters during the 19th and 20th centuries. In this context, we selected three representative examples. The German painter Johann Moritz Rugendas (1802-1858), known as Mauricio Rugendas, valued in several Latin American countries for his paintings of landscapes, people and plants. Prilidiano Pueyrredón (1823-1870), an outstanding Argentinian painter and architect that carried out important engineering works and beautification projects in Buenos Aires city, as well as his paintings entitled Un alto en el campo and Un alto en la pulpería. Juan Carlos 
Castagnino (1908-1972), Argentinian architect and artist, among whose works stand out his illustrations in the Martín Fierro by José Hernández published by the University of Buenos Aires.

The silversmith Juan Carlos Pallarols was the person in charge of the manufacturing of the Presidential batons from 1983 to 2015. Many of these items have adornments on their handles of 24 thistles, one for each province of Argentina, as well as three thistle buds representing the southern Atlantic islands. This symbolism supports the popular deeply-rooted local idea that thistles are natives of Argentina. However, the use of thistles in silversmithing may be of European inspiration. For instance, they were found on Viking metal objects from the 8th to 12th centuries, including "thistle flower brooches" from Ireland (Kelly 2007), and in Scotland, for the Scottish, the thistle is their national flower, a symbol of the tenacity of their national identity (Green 2010).

\section{Cynara cardunculus: particular} considerations

\section{Taxonomy and domestication}

Cynara cardunculus $\mathrm{L}$. is a species with a controversial taxonomy (Gutiérrez 2011; Gutiérrez and Sonnante 2014); even when, at present, it is usually considered to include three taxa: a) wild cardoon, C. cardunculus var. sylvestris (Lam.) Fiori $(=C$. sylvestris Lam.), a native of the eastern Mediterranean and recognized as the wild ancestor of the other two taxa, domesticated in the western Mediterranean; b) cultivated cardoon, $C$. cardunculus var. altilis DC., frequently naturalized in zones outside its origin area; c) artichoke, C. cardunculus subsp. scolymus (L.) Hegi (= C. scolymus L.). Wild cardoon is totally compatible and inter-fertile with both cultivated cardoon and artichoke, although the latter two would soon be separated from the wild cardoon (Raccuia et al. 2004).

Wild cardoon is a robust plant with big, spiny rosette-shaped leaves, and branched inflorescences with thorny involucral scales. Domestication was addressed to obtain cultivated less spiny taxa and for two useful purposes: a) to take advantage of its veins and foliar bases of lower leaves by means of earthing to bleach the petiole, thus becoming an edible organ store (cultivated cardoon), b) to take advantage of its capitula for food, particularly of the fleshy, spineless involucral scales (artichoke).

Agronomy historians along with botanists and geneticists agree in considering the species -taken as a whole- as both an archaeophyte as well as an ancient crop in the western Mediterranean, and later in other parts of the world, for instance South America. However, authors differ on which of the two entities was domesticated first, and whether the domestication processes occurred in Sicily during the Middle Ages or earlier, under the Islamic Culture in North Africa. In this sense, Gatto et al. (2013), Pignone and Sonnante (2004), Sonnante et al. (2007) think that artichoke domestication took place at about the beginning of the first millennium, possibly in Sicily, and was later spread by the Arabs during the Middle Ages. On the other hand, cultivated cardoon could have been domesticated in the first half of the second millennium in the western Mediterranean. This hypothesis is based on both molecular data originating from studies performed on individuals obtained from diverse germplasm banks and collections, and on historical documents produced by naturalists and agronomists of Greco-Roman antiquity (Theophrastus, Pliny, Columella). Not with standing, they do not take into 
consideration the contributions of medieval andalusí agriculturalists and other specialists (philologists, historians, agronomists), who studied that culture and its documents. On this basis, Andrew M. Watson, the agriculture historian most cited in the Islamic World, offers a different approach:

a) The eastern Mediterranean origin of the wild taxon, Cynara cardunculus var. sylvestris, has been accepted according to the results of molecular analyses performed by Gatto et al. (2013) and Sonante et al. (2007). For this reason, wild populations of C. cardunculus in the western Mediterranean (including the Iberian Peninsula) and even the populations introduced into southern South America (although this has to be confirmed by means of molecular biology) do not belong to that type of species but to naturalized $C$. cardunculus subsp. altilis (Fig. $1 \mathrm{a}, \mathrm{b})$.

b) During the Roman Empire only $C$. cardunculus subsp. altilis was grown in the western Mediterranean and is at present naturalized in that region.

c) C. cardunculus subsp. scolymus, was domesticated and cultivated in medieval times and in the Islamic World, maybe in the Maghreb, from where it possibly entered Sicily earlier than into other territories such as, for instance, the Iberian Peninsula (Watson 1998) (Fig.1 c).

\section{Cultivated thistle: culinary traditions on} both sides of the Atlantic

In current Spanish cuisine, as it was observed several times in different parts of the country and registered in published works (e.g. Pardo de Santayana et al. 2014), the thistles are always boiled and then prepared in various ways, all of them using olive oil. The simple seasoning of thistles with this oil is one of the most common ways to consume them, as well as in salads including other ingredients (like ham or shrimps); served with almond and olive oil sauce; fried with clams or cod; in omelets; pickled; in stews; or in the more traditional "esparragado", that is a stir-fry of bread or flour, garlic, paprika and eggs. This recipe is also used to prepare "tagarninas" (Scolymus) and other species of thistles in a broad sense. In Aragon and Catalonia, some recipes have been found that use milk or even cream to prepare béchamel sauce, adding almonds, nuts, raisins, and pine nuts. According to Pardo de Santayana et al. (2014), the petioles (called pencas) are eaten in different parts of Spain, raw in salads or cooked, fried or coated, with rice, and in vegetable stews. To prepare them their foliar laminae are removed, and their petioles cut and rubbed longitudinally with salt, or peeled to take off the whitish, bitter epidermis. In Catalonia, the inflorescences are used to curdle milk to prepare homemade cheese, highly appreciated for its taste.

In Italy, an alcoholic beverage used as an aperitif and digestive, named "Cynar", has been produced since 1953. Its consumption and manufacture spread during the 20th century to other Mediterranean countries, as well as to Latin America. In Argentina, for example, it became a popular drink immediately and is still produced as per the original Italian recipe. Although the formula remains secret, it is well known that its main ingredient is artichoke, and it contains about a dozen different herbs (Campari Group 2019).

Many localities of the Piedmont region (northwestern Italy) claim bagna cauda to be unique to it. In fact it originated long ago on the Provence coast (South of France), with the name anchoirade that is composed of raw vegetables cut into sticks, what are 
steeped in a sauce made of salty anchovies, garlic and olive oil. It is presumed that medieval merchants from Asti, a Piedmont city, encountered bagna cauda on their journeys to the zone to stock up on salt and anchovies, and then spread the dish to northwestern and southern Piedmont (Leoncini 2016). The ancient Provençal recipe was adapted by Asti peasants to vegetables that were more common as food in popular country communities. For a long time, it conserved this popular nature, and was despised by the upper-class, presumably for its invasive garlic flavor. Therefore, this recipe does not appear before 1875 in Piedmont gastronomic testimonies, and was first described by Roberto Sacchetti (1847-1881) in accordance with the dish still current in this region of Italy: a paste of anchovies, garlic and olive oil made into a hot sauce placed in the middle of the table and in which diners could dip diverse vegetables (with the exception of aromatic ones, like celery or fennel), with "cardo gobbo" (hunchback thistle) standing out among them, a thistle from Niza Monferrato (appellation of origin) (Geraci 2017).

Piedmont immigrants arrived in Argentina in 1860 and settled in the so-called "Pampa Gringa" (provinces of Santa Fe and Córdoba and, to a lesser extent, in Entre Ríos and Buenos Aires); there, they generated the largest milk catchment in South America (Gori 1988). According to the statements of immigrants' descendants, the abundance and cheapness of cream were the cause of the gradual replacement of the more expensive olive oil. For Piedmont peasants and their descendants, bagna cauda is a winter food, symbolizing fraternity and happiness it constitutes a tradition transmitted from generation to generation, and is even present in urban areas. Its importance lies in that, with bagna cauda, the vegetable side dish had arrived. Thus, it is said that in immigrants' gardens, cardoons were grown practically only for their use in this dish. However, although bagna caudais still widespread at present, cardoon consumption has decreased, having been displaced by other crops, and also by foods of an animal origin.

Consequently, cultivated thistles are seldom offered at greengrocer's shops (Rapoport et al. 2003). Wild thistles are even more rarely used, except for certain individual cases, like a restaurant in the department of Magdalena (Buenos Aires province), that serves diverse dishes prepared with "weeds", including thistle petioles, both boiled and pickled. In addition, at Comahue University (Viedma, Río Negro province), different assays have been carried out to make cookies and pastry with whole plants of Cynara cardunculus var. altilis (including their spines), dehydrated, ground and mixed with wheat flour (Rapoport et al. 2009). However, it should be noted that this taxon, as a weed, was officially declared to be an agricultural pest in 1963 by the Argentine government, so its control is mandatory (Rapoport et al. 2009).

\section{Cultivated thistle and artichoke} inpresent-day Argentina

Cynara cardunculus var. altilis, is both the wild thistle, known in Argentina as "cardo de Castilla", and the cultivated thistle (cardoon). It is of importance only as a regional crop currently in Europe in several parts of Spain, France and Italy (Raccuia et al. 2004). In Argentina, it is cultivated on a commercial scale in Buenos Aires province, in the area denominated La Plata horticultural belt (Pochettino et al. 2014) and it is usually sold rootless in packs of four plants. Its 
consumption is limited and it is mainly eaten by members of the Piedmont community and their descendants (Cravero 2007). As mentioned above, its sale in greengrocers in urban areas is sporadic. The varietal nature of cultivated material is not known with any certainty, but it includes several cultivars like 'Cardo Blanco', 'Cardo Semence', and 'Cardo Florensa', although the two latter ones seem to be trademarks (Cravero et al. 2007; Espósito et al. 2011). In Spain, the cultivars include: 'Blanco de tours', 'Lleno sin pinchos de España', 'Blanco de ivoire', 'Lleno blanco', 'Blanco mejorado', 'Raza Bérgamo', and 'Verde inerme' (Maroto 2002).

As for Cynara cardunculus subsp. scolymus, the artichoke, for a long time this was cultivated in Argentina in an estimated area of about 4000 hectares. However, since 1980 , a significant reduction of the cultivated area has taken place, due mainly to its loss of profitability, although this diminution has not been reflected in its consumption (2.6 $\mathrm{kg} /$ person/year). At present, the cultivated area is nearly 2000 hectares (Larrazabal and García 2014). The major production area is located on the outskirts of La Plata (Buenos Aires province), representing $64 \%$ of Argentinian production (Fig. 1 d). Other production zones include Santa Fe (14\%), and Mendoza and San Juan provinces (19\%) (Cravero 2007). This cultivation is based on two cultivars: 'Ñato' (of uncertain origin and almost extinguished, but recognized as own variety by producers of La Plata horticultural belt), and 'Francés' (which is in fact the 'Romanesco' cultivar, originating in Lazio, central Italy, one of the best known cultivars, with purple capitula). In other areas of Argentina, those "white" cultivars, derived from the Spanish cultivar 'Blanco de Tudela', prevailed, giving the 'Criollo' or 'Blanco Argentina', that was more suitable for manufacturing. The present production is based on those cultivars by means of clonal propagation, and the surface devoted to seed culture is still very limited (Larrazabal and García 2014).

\section{Naturalized thistle and re-signification} of its uses

As in other works above mentioned, the effectiveness of a multidisciplinary vision in ethnobotanical research is demonstrated. The simultaneous use of documentary sources such as historical texts of very different nature (agronomic, botanical, literary texts, narrations of famous travelers, culinary treatises, historical archives) artistic manifestations (paintings, pottery, silversmithing) and archaeological remains has allowed us to analyze the travel and transfer of the rich "Mediterranean culture of thistles" towards South America, identifying particular processes such as the resignification of the uses of Cynara cardunculus

Effectively, Cynara cardunculus var. altilis, has been early introduced by Spanish and naturalized in southern South America, mainly in the pampas of Argentina and Uruguay, and also in central Chile (Gutiérrez et al. 2017). The expansion without human intervention of these plants in the new geographical context was very extensive, to the point that, as we discussed earlier, these thistles were considered locally as a symbol of the wild. In this framework, the divergence between "native" and "exotic" plants, usual in biology, differs from the established by the local botanical knowledge that distinguishes between "cultivated" and "wild" plants (which grow spontaneously, thus including both native and naturalized ones in biological terms). Similar approaches have been used in Argentina when studying, for instance, fruit 


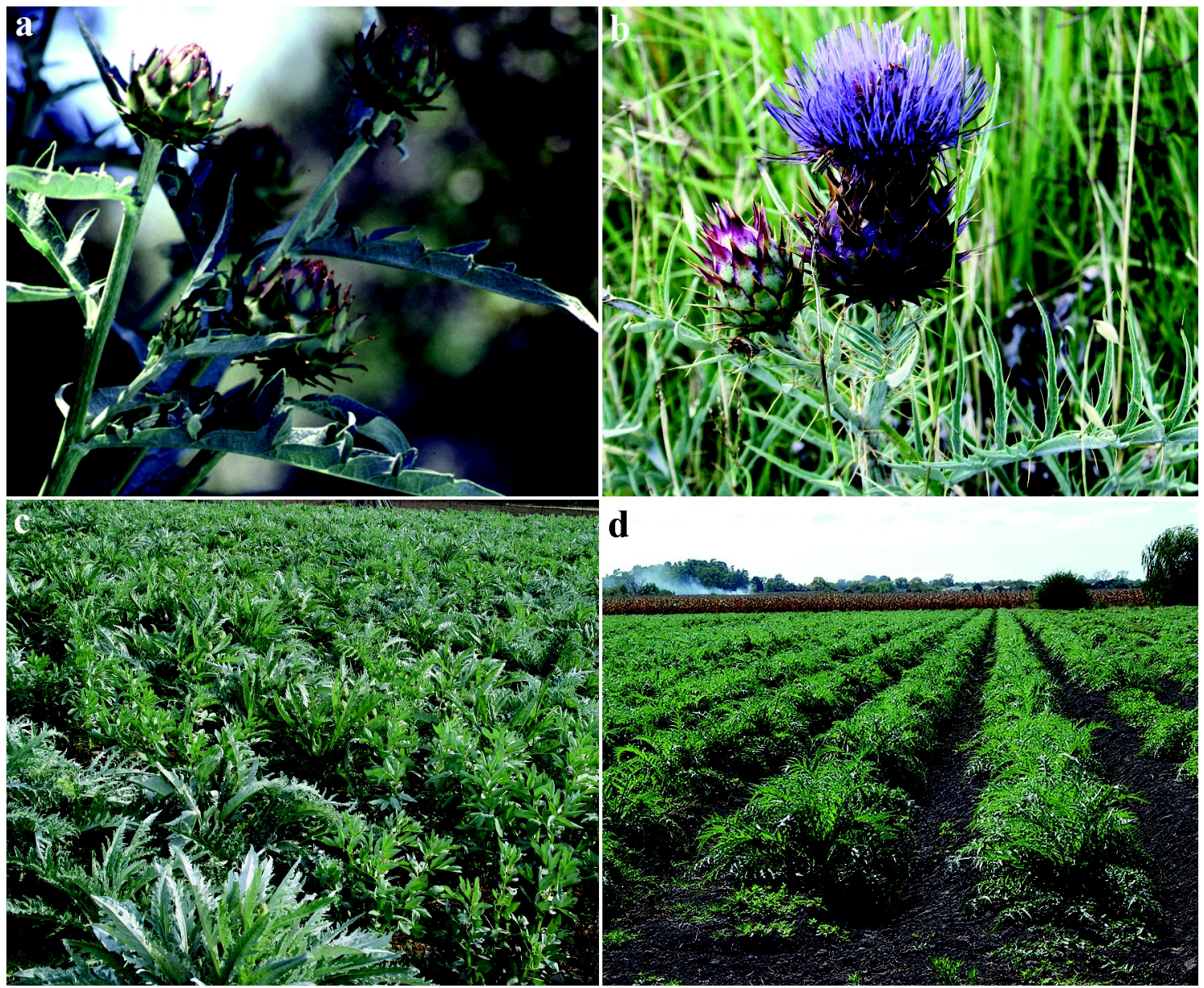

Figure 1. Cynara cardunculus subsp. altilis naturalized in Córdoba, Andalucía, Spain (a) and between Bahia Blanca and Olavarría, Buenos Aires, Argentina (b). Cynara cadunculus subsp. scolymus cultivated in Vélez-Málaga, Andalucía, Spain (c), and near La Plata, Buenos Aires, Argentina (a, b, c: by E. Hernández Bermejo; d: Néstor D. Bayón).

trees in the northeast and northwest of the country (Hilgert et al. 2014), or in reflecting on the contribution of ethnobotany to the study of the naturalization process (Hurrell and Delucchi 2013).

As Gama and collaborators say: "Although many studies have attempted to understand the complexity of relationships between humans and their environments, it is still necessary to advance the understanding of the human behavior associated with these relationships" (Gama et al. 2018). In this context, the local uses of Cynara cardunculus var. altilis have undergone processes of re-signification over time. The re-signification (Hurrell 2014) sometimes includes the adjustment of some uses of the original biocultural context (the Iberian Peninsula) to the local biocultural context (Argentina); e.g., the culinary uses mentioned above. Other times, the resignification includes the adjudication of new uses (absent in the original biocultural context); e.g., the use of these plants as emergency fuel, according to the local needs. This case exemplifies the concept of biocultural adaptation, in terms of Gama et al. (2018).

In regard to popular medicine, both in Spain (Pardo de Santayana et al. 2014) and in Argentina (Hurrell and Puentes 2013), the following medicinal uses are registered: 
depurative, hypotensive, digestive, cholesterol-lowering, hepatoprotective, cholagogue, choleretic, and antidiabetic. Medicinal uses registered only in Spain: antidiarrheal, anti-constipation, antihemorrhagic, and vulnerary. Medicinal uses registered only in Argentina: appetizer, antispasmodic, antacid, diuretic, antinephritic, antilithic, antirheumatic, slimming, and aphrodisiac. In this frame, some traditional uses in Spain are conserved in Argentina, other medicinal uses in Spain are lost in Argentina, and other uses are novel in Argentina regarding Spain.

\section{CONCLUSIONS}

According to the historical documents from the western Mediterranean review, nearly 20 taxa constituted the "thistle culture" in antiquity, i.e. those it was possible to identify in the texts. This level of bio- and agro-diversity rose to at least 25 species during the andalusi Middle Ages in the Iberian Peninsula. Then, since the Renaissance and under the regime of Christian Iberian culture, the amount fell to less than 10 taxa. During the 15th century, the "thistle culture" was to a great extent lost, although it has been kept alive up to today due to the traditional dissemination of popular Iberian wisdoms. Thus, a heritage of about 90 species of thistles of the Asteraceae family is accounted for in contemporary ethnobotanical studies. By the 16th century, these plants and their associated knowledge had been transferred to southern South America, along with the naturalization processes of those thistles introduced both voluntarily (the cultivated ones) or involuntarily (weeds).

Regarding their transfer to the territory of what is now Argentina and to the local creole cultures, many thistle species spread extensively throughout the pampas and constituted from those early moments a wild resource to be employed as emergency food, as plants with therapeutic uses, some of them still in use, as well as a source of low-quality fuel, used to resolve the scarcity of woody plants. With this background naturalized thistle expansion became a symbolic element of identity for pampas inhabitants, as is shown in comments from travelers, as well as in the works of painters, silversmiths, and men of letters. Even now, many local people consider the thistles as native plants which are typical of each local situation.

In spite of what has been said above, since the 18th century the food culture of thistles has been lost, including the consumption of Cynara cardunculus, introduced by Spanish into the New World. In the particular case of Argentina and the three intra-specific taxa of Cynara cardunculus, it can be concluded that:

a) It is not possible to confirm the presence of Cynara cardunculus var. sylvestris in Argentina, and the naturalized populations probably belong to $C$. cardunculus var. altilis.

b) In present-day Argentina, the cultivation of Cynara cardunculus var. altilis is restricted, above all, to families of descendants of Italian immigrants. It was possibly introduced with the first arrival of the Spanish during the 16th century, but, as time went by, it became a marginalized, even neglected, crop, simultaneously with its naturalization. For this reason, it is assumed that a second introduction took place in about 1870 by Italian immigrants.

c) The cultivation of Cynara cardunculus subsp. scolymus in Argentina began towards the end of the 19th century, mainly with the arrival of Italian and Spanish immigrants, who introduced the first cultivars and 
adapted their traditional agricultural practices to local environmental conditions.

Summing up, despite the above mentioned loss and as is evidenced by the present diversity of food knowledge, a resignification process can be observed, due to the arrival of Spanish and Italian immigrants. Traditional cooking that is still kept up in rural areas in the center of the country validates this process, whose analysis proves the great opportunities offered by "cardos de Castilla" and "alcauciles", in local horticultural and food innovation in Argentina.

\section{ACKNOWLEDGMENTS}

This work has been carried out under the objectives program of the CultIVA-CYTED network. We appreciate the collaboration of the entire team that of the CYTED Secretariat to meet the proposed objectives. In particular and in relation to this contribution we would like to thank also the help and cooperation in the administration tasks and communication among network members of Paquita Tarifa (BGVA and IMGEMA Jardín Botánico de Córdoba, Spain) and Diana Badder's review of the English version of this manuscript. Also, the authors value the suggestions of the anonymous reviewers and especially acknowledge all those people who shared their time and wisdom and consent in the publication.

\section{REFERENCES}

Abū I-Jayr. (2004) [11th century] Kitābu'Umdat al-abībfima rifat al-nabāt.CSIC, Madrid, Spain

Albuquerque UP, da Cunha LVFC, Lucena RFP, Alves RRN (2014) Methods and Techniques in Ethnobiology and Ethnoecology. SpringerHumana Press, New York, USA
Alonso J (2004) Tratado de Fitofármacos y Nutracéuticos. Corpus, Buenos Aires, Argentina

Baso C (1998) [4th century] Geopónica. INIA, Madrid, Spain

Benites MJ (2013). "Vigilias, fatigas y peregrinaciones": viaje, relato y desamparo en los confines del imperio. Telar 11-12:80-97

Boutelou C, Boutelou E (1801) Tratado de la Huerta. Villalpando, Madrid, Spain

Campari Group (2019) Cynar. The artichoke liqueur known for its versatility and taste [https://www.camparigroup.com/en/brands/liqueu rsothers/cynar?legalRadio=1\#legalage]

Accessed January 30th 2019

Cardiel J (1930) [1748] Diario del viaje y misión al Río del Sauce realizado en 1748. Coni, Buenos Aires, Argentina

Carrió de la Vandera A (1997) [1771]. El lazarillo de ciegos caminantes. Emecé. Buenos Aires, Argentina

Clusio (2005) [1576] Descripción de algunas plantas raras encontradas en España y Portugal. Junta de Castilla y León, Valladolid, Spain

Colmeiro M (1885) Enumeración y revisión de las plantas de la Provincia Hispano-Lusitana é Islas Baleares. Fuentenbro, Madrid, Spain

Columela (1988) [42 AD] De los trabajos del campo. Siglo XXI, Madrid, Spain

Correa RF, Delucchi G, Charra G (2003) Etnobotánica de los "cardos" en la Argentina. Delpinoa 45:149-156

Cravero V (2007) Incorporación de metodología no convencional en un plan de mejora vegetal. Universidad Nacional de Rosario, Santa Fe, Argentina

Cravero V, Martín E, Cointry E (2007) Genetic Diversity in Cynara cardunculus determined by SRAP markers. Journal of The American Society for Horticultural Science 132:208-212

D’Orbigny A (1945) [1826] Viaje a la América Meridional II. Futuro, Buenos Aires, Argentina

Dantín Cereceda J (1943) Catálogo metódico de las plantas cultivadas en España. Ministerio de Agricultura, Madrid, Spain 
Darwin C (1839) The narrative of the voyages of H.M. Ships Adventure and Beagle. III. Journal and remarks 1832-1836. Colburn, London, UK

Del Río JP, Maidana JA, Molteni A, Pérez M, Pochettino ML, Souilla L, Tito G, Turco E (2007) El rol de las "quintas" familiares del Parque Pereyra Iraola (Buenos Aires, Argentina) en la conservación de la agrobiodiversidad. Kurtziana 33(1):217-226

Delucchi G, Charra G (2012) La flora y vegetación pampeana vistas por cronistas y viajeros de los siglos XVIII y XIX. Historia Natural, III Serie 2(1):73-83

Delucchi G, Gutiérrez DG (2014) Cardueae. In: Zuloaga FO, Belgrano MJ, Anton AM (eds.) Flora Argentina, Asteraceae 7 (1). Instituto de Botánica Darwinion, San Isidro, Buenos Aires, Argentina, pp: 224-225

Delucchi G, Correa RF, Charra G (2002) Génesis del complejo de los "cardos" en la Región Pampeana (Argentina). Delpinoa 45:143-148

Espósito M, Martin E, Cravero V, Cointry E (2011) Uso de marcadores morfológicos, bioquímicos y moleculares SRAP para diferenciar variedades de Cynara cardunculus L. (Asteraceae). Revista de la Facultad de Ciencias Agrarias, UNCuyo 43(2):35-45

Font Quer P (1961) Plantas medicinales. El Dioscórides renovado. Labor, Barcelona, Spain

Gálvez Ramírez C, Hernández Bermejo E (1986) Fundamentos para la domesticación de especies silvestres ibéricas de Cardueas con interés potencial agrícola. Actas del II Congreso Nacional de la Sociedad Española de Ciencias Hortícolas. `Córdoba, Spain

Gálvez Ramírez C, Hernández Bermejo E (1990) Life cycle and adaptive strategies of three non-annual ruderal Cardueae: Onopordum nervosum, Carthamus arborescens and Cirsium scabrum. Plant Systematics and Evolution 171:117-129

Gama ADS, de Paula M, da Silva RRV, FerreiraJúnior WS, Medeiros PM (2018) Exotic species as models to understand biocultural adaptation: Challenges to mainstream views of human-nature relations. PLoS ONE 13(4): e0196091.

https://doi.org/10.1371/journal.pone.0196091.

Accessed January 30th 2019
García Sánchez E (2009) Ibn al-Awwam, Abu Zakariya'. Biblioteca de al-Andalus 2:444-451

Gatto A, de Paola D, Bagnoli F, Vendramin G, Sonnante G (2013) Population structure of Cynara cardunculus complex and the origin of the conspecific crops artichoke and cardoon. Annals of Botany 112(5):855-865

Geraci V (2017) La bagna caoda. Associazione Italiana Food Blogger. [https://www.aifb.it/calendario-del-cibo/giornata-

nazionale-della-bagna-caoda/] Accessed January 30th 2019

Gómez de Ortega C (1784) Continuación de La Flora Española. Ibarra, Madrid, Spain

Gómez de Ortega C, Muñoz de Ugena M (1791) Flora Española Selecta. Barco López, Madrid, Spain

González de Nájera A (1889) [1614] Desengaño y reparo de la Guerra del Reino de Chile. Ercilla, Santiago, Chile

Gori G (1988) Inmigración y colonización en Argentina. Eudeba, Buenos Aires, Argentina

Green J (2010) Scottish Miscellany: Everything You Always Wanted to Know about Scotland the Brave. Skyhorse, New York, USA

Gutiérrez DG (2011) Cynara cardunculus L. (Asteraceae, Cardueae): estudios biogeográficos en América del Sur austral. Boletín de la Sociedad Argentina de Botánica 46(Suppl.):100

Gutiérrez DG, Delucchi G (2011) Estado actual de los "cardos" (Asteraceae, Cardueae) introducidos en América del Sur austral. Boletín de la Sociedad Argentina de Botánica 46(Suppl):193-194

Gutiérrez DG, Sonnante G (2014). Cynara. In: Zuloaga FO, Belgrano MJ, Anton AM (eds.) Flora Argentina, Asteraceae 7 (1). Instituto de Botánica Darwinion, San Isidro, Buenos Aires, Argentina, pp: $290-291$

Gutiérrez DG, Garcia-Jacas N, Susanna A (2014) Plectocephalus. In: Zuloaga FO, Belgrano MJ, Anton AM (eds.) Flora Argentina, Asteraceae 7 (1). Instituto de Botánica Darwinion, San Isidro, Buenos Aires, Argentina, pp: 293-294 
Gutiérrez DG, Rodríguez-Cravero JF, Grossi MA, Yañez A, Stampacchio ML (2017) Modelado actual de la distribución de Cynara cardunculus (Asteraceae, Cardueae) en el sur de América del Sur. Boletín de la Sociedad Argentina de Botánica 52(Suppl):127-128

Hernández J (1967) Martín Fierro. The Argentine Gaucho epic. State University of New York, USA

Hernández Bermejo E (1991) Botanical foundations for the restoration of Spanish Arabic Gardens: Study of the plant species used and their introduction during the Andalusi Period. In: Tjon Sie Fat L, de Jong E (eds.) The Authentic Garden. Clusius Foundation, Leiden, Netherlands, pp: 153-164

Hernández Bermejo JE, León J (1994) Neglected Crops: 1492 from a different perspective. FAO, Rome, Italy

Hernández Bermejo JE, García Sánchez E (1998) Economic botany and ethnobotany in alAndalus (Iberian Peninsula: Tenth-Fifteenth Centuries), an unknow heritage of mankind, Andalusí Middle Ages. Economic Botany 63:6066.

Hernández Bermejo JE, García Sánchez E (2000) Botánica económica y etnobotánica en al-Andalus (Península Ibérica: siglos X-XV): un patrimonio desconocido de la humanidad. Arbor CLXVI, 654:311-331.

Hernández Bermejo JE, García Sánchez E (2015) Huertas del Generalife: en busca de la autenticidad. Patronato de la Alhambra y Generalife, Granada, Spain

Hernández Bermejo JE, García Sánchez E, Carabaza J (2013a) Flora Agrícola y Forestal de al-Andalus. Magrama, Madrid, Spain

Hernández Bermejo JE, Navarro-Burgos $M$, García-Sánchez E (2013b) The Huertas of the Generalife in the Alhambra, an approach to the evolution of this landscape based on travelers' account. Studies in the History of Gardens and Designed Landscapes 33(1):52-70.

Hernández Bermejo JE, Herrera-Molina $F$, Prados-Ligero J, Díaz-López M (2009) The Andalusian Seed Bank: Conserving our natural heritage. Acta Horticulturae 812:559562.
Hernández Bermejo JE, Torrent Castellet J, Parra Rincón M, Pujadas Salvá A, Clemente Muñoz M, Prados Ligero J (1991) Prospección e identificación de especies vegetales de elevada rusticidad y producción de biomasa transformable. In: Fernández-Cavada JL (ed.) Agroenergética. CICYT, Madrid, Spain, pp: 93131

Herrera A (1818) [1513] Agricultura General. Imprenta Real, Madrid, Spain

Herrera y Loizaga JC (1785) Viajes de España a Buenos Aires, Córdova, Mendoza, Potosí, Chile i Lima en los años 1713 i 1717. Sevilla, Spain

Hieronymus J (1882) Plantae Diaphoricae. Florae Argentinae. Kraft, Buenos Aires, Argentina

Hilgert NI, Lambaré DA, Vignale ND, Stampella PC, Pochettino ML (2014) ¿Especies naturalizadas 0 antropizadas? Apropiación local y la construcción de saberes sobre los frutales introducidos en época histórica en el norte de Argentina. Revista Biodiversidad Neotropical 4(2):69-87.

Huici Miranda A (2016) La cocina HispanoMagrebí durante la época almohade. Trea, Gijón, Spain

Hurrell JA (2014) Urban Ethnobotany in Argentina: Theoretical advances and methodological strategies. Ethnobiology and Conservation 3:2

Hurrell JA, Delucchi G (2013) Aportes de la Etnobotánica al estudio de las invasiones biológicas. Casos en la región rioplatense (Argentina). Historia Natural, III Serie 3(2):6176.

Hurrell JA, Puentes JP (2013) Medicinal and aromatic species of Asteraceae commercialized in the conurbation Buenos Aires-La Plata (Argentina). Ethnobiology and Conservation 2:7.

Ibn al-Awwam (1988) [12th century] Kitāb alFilāa. Libro de Agricultura. 2 vol. (ed. facs. con estudio preliminar y notas por Hernández Bermejo E, García Sánchez E). Madrid, Spain

Ibn al-Baytar (1877) [ca. 1235] Aljami' limufradat al-adwiyawa'l-aghdhiya. Traité des Simples. Imprimerie Nationale, Paris, France

Ibn Bassal (1995) [11th century] Kitāb al-Qa dwa-I-bayān. Libro de Agricultura. Sierra Nevada, Sevilla, Spain 
Ibn Razin al-Tugibi (2007) [ca. 1240] Fuālat aljiwān. Relieves de las mesas, acerca de las delicias de la comida y los diferentes platos. Trea, Gijón, Spain

Isidoro de Sevilla (1982) [ca. 630] Etimologías. BAC, Madrid, Spain

Kelly E (2007) Guía del Museo Nacional de Irlanda. Arqueología. National Museum of Ireland, Dublín, Ireland

Lamas A (1873) [1745] Historia de la conquista del Paraguay, Río de la Plata y Tucumán escrita por el Padre Pedro Lozano. Imprenta Popular, Buenos Aires, Argentina

Larrazabal M, García SM (2014) La producción de alcachofa en Argentina. [https://es.slideshare.net/marianolarra/alcachofa38307830] Accessed May 26th 2018

Leoncini S (2016) Bagna Cauda: Storia di Acciughe, Sale e Contrabbando. [http://lamascaincucina.it/la-bagna-cauda-e-leacciughe-a-cuneo/] Accessed January 30th 2019

Lev E, Amar Z (2008) Practical Materia Medica of the Medieval Eastern Mediterranean According to the Cairo Genizah. Brill, Leiden, Netherlands

Mac Cann W (1985) [1847] Un viaje a caballo por las provincias argentinas. Hyspamerica, Buenos Aires, Argentina

Maroto J (2002) Horticultura Herbácea Especial. Mundiprensa, Madrid, Spain

Martínez-Crovetto R (1968) Estudios Etnobotánicos III. Nombres de plantas y su utilidad según los indios araucano-pampas del oeste de Buenos Aires (Argentina). Etnobiológica 12:1-14.

Martínez-Crovetto R (2012) Estudios Etnobotánicos V. Nombres de plantas y su utilidad según los Mbya-guaraní de Misiones, Argentina. Bonplandia (Corrientes) 21(2):109133.

Marzocca A (1977) Vademécum de malezas medicinales de la Argentina, indígenas y exóticas. Orientación Gráfica Editora, Buenos Aires, Argentina

Molina RA (1955) Primeras crónicas de Buenos Aires. Las dos memorias de los hermanos Massiac. 1660-1662. Lumen, Buenos Aires, Argentina
Morales Valverde R (2006) Flora literaria del Quijote. Instituto de Estudios Albacetenses, Albacete, Spain

Moreno JC et al. (2008) Lista Roja 2008 de la flora vascular española. Ministerio de Medio Ambiente y Sociedad Española de Biología de la Conservación de Plantas, Madrid, Spain

Mori J (1941)[1535] Relación de lo ocurrido en la expedición de Simón de Alcazaba. Revista de la Biblioteca Nacional (Buenos Aires) 5(19):401-412

Ochoa J, Ladio A (2011) Pasado y presente del uso de plantas silvestres con órganos de almacenamiento subterráneos comestibles en la Patagonia. Bonplandia (Corrientes) 20(2):265-284

Ovalle A (1646) Histórica relación del Reyno de Chile. Cauallo, Rome, Italy

Paladio R (1990) [4th century] Tratado de agricultura. Gredos, Madrid, Spain

Pardo de Santayana M, Morales R, AceitunoMata L, Molina M (2014) Inventario Español de los Conocimientos Tradicionales relativos a la Biodiversidad. Magrama, Madrid, Spain

Pardo Sastrón J (1895) Catálogo o enumeración de las plantas de Torrecilla de Alcañiz, así espontáneas como cultivadas. Casañal, Zaragoza, Spain

Parish Robertson J, Parish Robertson W (1988) [1838]. Cartas sobre el Paraguay. Hyspamerica, Buenos Aires, Argentina

Pastor Artigues B (1987) Marco Gavio Apicio: Cocina romana. Coloquio, Madrid, Spain

Pigafetta A (1986) [1536] Primer viaje alrededor del globo. Orbis, Barcelona, Spain

Pignone D Sonnante G (2004) Wild artichokes of south Italy: did the story begin here? Genetic Resources and Crop Evolution 51:577580

Plinio.1999 [ca. 77 AD] Historia Natural. 3 vols. Visor, Madrid, Spain

Pochettino ML (2005) Verduras en Europa, yuyos en América: prácticas y conocimientos sobre malezas comestibles. Actas Congreso Nacional de Inmigración y IV Congreso de Historia de los pueblos de la provincia de Santa Fe. Esperanza, Santa Fe, Argentina. 
Pochettino ML, Hurrell JA, Bonicatto M (2014) Horticultura periurbana: estudios etnobotánicos en huertos familiares y comerciales de la Argentina. Ambienta (España) 107:86-99

Quer J (1762). Flora española. Ibarra, Madrid, Spain

Raccuia SA, Mainolfi A, Mandolino G, Melilli M (2004) Genetic diversity in Cynara cardunculus revealed by AFLP markers: comparison between cultivars and wild types from Sicily. Plant Breeding 123:280-284

Rapoport EH, Sanz EH, Ladio AH (2003) Plantas silvestres comestibles de la Patagonia argentino-chilena. Exóticas. Parte II. Imaginaria, Bariloche, Argentina.

Rapoport EH, Marzocca A, Drausal BS (2009) Malezas comestibles del Cono Sur. INTA, Buenos Aires, Argentina

Richardson DM, Pyšek P, Rejmánek M, Barbour M, Dane Panetta F, West CJ (2000) Naturalization and invasion of alien plants: concepts and definitions. Diversity and Distributions 6:93-107

Rípodas Ardanaz D (2002) Viajeros al Río de la Plata, 1701-1725. Academia Nacional de Historia, Buenos Aires, Argentina

Salmon P (1984) Le voyage de M. de Massiac en Amérique du Sud au XVII siècle. Académie Royale des Sciences D'Outre-Mer Mémoires (Nouvelle Série) 47(3):5-61

Schmidl U (2009) [1567] Viaje al Río de la Plata. Claridad, Buenos Aires, Argentina
Sonnante G, Pignone D, Hammer K (2007) The domestication of artichoke and cardoon: from Roman times to the Genomic age. Annals of Botany 100(5):1095-1100

Susanna A, Garcia-Jacas N (2007) Cardueae. In: Kubitzki K (ed.) The Families and Genera of Vascular Plants VIII. Asterales. Springer, Berlin, Germany, pp: 123-147

Susanna A, Garcia-Jacas N (2009) Cardueae. In: Funk VA, Susanna A, Stuessy TF, Bayer RJ (eds.) Systematics, Evolution, and Biogeography of Compositae. IAPT, Vienna, Austria, pp: 293313

Teofrasto (1988) [ca. 350-287 BC] Historia de las Plantas. Gredos, Madrid, Spain

Toursarkissian M (1980) Plantas Medicinales de la Argentina. Hemisferio Sur, Buenos Aires, Argentina

Verde A, Fajardo J, Rivera D, Obón C (2000) Etnobotánica en el entorno del Parque Nacional de Cabañeros. Parques Nacionales, Madrid, Spain

Vivar J de (2001) [1558] Crónica de los Reinos de Chile. Dastin, Madrid, Spain

Watson AM (1998) Innovaciones en la agricultura en los primeros tiempos del mundo islámico: difusión de los distintos cultivos y técnicas agrícolas del año 700 al 1100. Universidad de Granada, Granada, Spain

Woodbine Hinchliff T (1955) [1861] Viaje al Plata en 1861. Hachette, Buenos Aires, Argentina

Received: 29 November 2018

Accepted: 28 February 2019

Published: 12 March 2019 